\title{
Evaluation of Consolidated Financial Performance Analysis of Dedebit Credit \& Saving Institution (DECSI)
}

\author{
Teshale Berhane ${ }^{1}$, Mohammedawel Yesuf ${ }^{2}$, Kifle Negash ${ }^{3}$ \\ ${ }^{1}$ Accounting and Finance, Adigrat University, Ethiopia \\ ${ }^{2}$ Economics, Adigrat University, Ethiopia \\ ${ }^{3} \mathrm{NBE}$, Addis Ababa, Ethiopia
}

\begin{abstract}
The study entitled "Evaluation of consolidated financial performances analysis" was conducted on DECSI. The study answered the following research questions: (1) what seems the financial performance of Dedebit credit \& saving institution over the years? (2) How is the operating profitability and efficiency of Dedebit credit \& saving institution over the years? (3) What are the indicators of the financial and operational performances of Dedebit credit \& saving institution over the years? The data used in this study was entirely a 3 years secondary data only. As the aim of this study was to evaluate the consolidated financial performance analysis, an audited financial statement of DECSI which has been reported to the National Bank of Ethiopia was used. The collected data were analyzed using different financial and operating performance indicators, and ratio analyses were applied to evaluate the financial sustainability and profitability; portfolio quality, and efficiency of DECSI over the study period. The performance of DECSI in managing its assets to generate a net profit has been positive all over the study periods. Although, the ROA in 2014 G.C was greater than the previous year's, DECSI's ROA was slightly decreased in 2015 G.C. DECSI had a ROE of 12.88\% in 2014 which was the highest figure from the rest of the study periods. In 2015 DECSI's ROE was slightly reduced compared to that of the preceding year. DECSI's operational self-sufficiency was above the threshold of 1, i.e. all over the study years the institutions' OSS were more than 1 which implies the institution's operating revenue is sufficient enough to cover all of its operating expenses. According to the DR results, DECSI's dependency ratio has been decreasing from year to year $(15.44 \%$ in 2013 to $13.60 \%$ in 2014 and again reduced to $12.73 \%$ in 2015) all over the study periods which is a good indicator that the institution has been able to increase its rely on own equity and operational revenues. With regard to the operating efficiency, DECSI attains lower ratio (i.e., 13.14\%) in the year 2015. From this, one can conclude that DECSI incurred almost 13 cents for administration and personnel (operating) expense in turn to provide a $\$ 1$ average gross loan portfolio to its customers in the year 2015.
\end{abstract}

Keywords: Dedebit credit \& saving institution, Microfinance, Tigray, Consolidated sinancial statement, and Ratio analysis

\section{Introduction}

\subsection{Background of the Study}

One of the most stylized facts of developing economies is that formal financial institutions leave the poorest population tightly constrained in their access to financial services. It is also widely recognized that economic progress relies largely on access to financial services such as savings, insurance, and credit. Where formal financial institutions fail the large majority of the poor population, there is evidence to support the proposition that microfinance institutions \& credit unions can fill some of the gap (Barham, Boucher and Carter, 1996 as cited in Alemayehu 2008).

Micro-finance institutions are an institution which provides financial services to low-income individuals or to those who do not have access to typical banking services. Microfinance is also the idea that low-income individuals are capable of lifting themselves out of poverty if given access to financial services (www.kiva.org/about/microfinance).

Micro-finance institutions (MFIs) are often defined in terms of the following characteristics: targeting the poor (especially the poor women); promoting small businesses; building capacity of the poor; extending small loans without collaterals; combining credit with savings; and charging commercial interest rates. MFIs are often innovative and flexible in their design and implementation (Dejene, 1998).

Microfinance (MF) is seen as one of the most efficient instruments to promote economic development and to fight poverty in poorer countries. Numerous microfinance institutions (MFIs) all over the world have proven that financial services can be offered on a sustainable basis with high outreach.

In Ethiopia the development of microfinance institutions is a recent phenomenon. The proclamation, which provides for the establishment of microfinance institutions, was issued in July 1996. Since then, various microfinance institutions have legally been registered and started delivering microfinance services (Wolday, 2000 as cited in Ebisa et al., 2012).

Ethiopian microfinance sector is characterized by its rapid growth, an aggressive drive to achieve scale, a broad geographic coverage, a dominance of government backed Microfinance Institutions (MFIs), an emphasis on rural households, the promotion of both credit and savings products, a strong focus on sustainability and by the fact that the sector is Ethiopian owned and driven. 


\section{International Journal of Science and Research (IJSR) \\ ISSN (Online): 2319-7064}

Index Copernicus Value (2013): 6.14 | Impact Factor (2015): 6.391

As these micro-finance sectors play a pivotal role in the socio - economic wellbeing of the poorer society, such institutions' performance monitoring, analysis and control needs special analysis in respect to their operation and performance results from the viewpoint of different audiences, like investors/owners, regulators, customers/clients, and management themselves.

\subsection{Background of the Organization}

Dedebit Credit and Savings Institution (DECSI) was established in March 1997 as a microfinance institution (MFI) providing credit and savings services for the rural and urban poor in the Tigray region of Ethiopia. DECSI evolved from a program established by the Relief Society of Tigray (REST), a local NGO founded in 1978. In 1993, REST conducted a socio-economic study on rural poverty in Tigray that indicated an unmet demand for finance by the rural poor. Based on this study, the Rural Credit Scheme in Tigray (RCST) was established under REST in the following year.

The goal of RCST was to provide affordable and accessible microfinance services to poor communities in the Tigray region. Due to the rapid growth of its operations, RCST formally registered in 1997 with the National Bank of Ethiopia, the country's central bank, and began operation as an MFI under its new name Dedebit Credit and Savings Institution.

The mission of DECSI is to provide microfinance services to individuals not able to access the formal financial sector. The ownership structure of DECSI is 25 percent government-owned and 75 percent owned by nongovernmental organizations (NGOs), farmers associations and women and youth associations. DECSI maintains 139 offices which employ 1,887 staff (http://www.bds-ethiopia.net/finance/dedebit.html).

The products and services provided by DECSI fall into three categories: loans, voluntary savings and fund transfer services. DECSI's loan products are as follows:

- General Loans have a maximum loan amount of ETB 5,000 (USD 392) and a maximum loan term of 12 months. General loans are typically given for income generating activities, such as agriculture, trade and handicrafts ethiopia.net/finance/dedebit.html).

(http://www.bds-

- Agricultural Package Loans have a maximum loan amount of ETB 5,000 (USD 392) and a maximum loan term of 12 months. These loans provide rural households that qualify under government-sponsored "Agricultural Package Program, food security at the household level by financing the purchase of dairy cows, dairy goats, beehives, water pumps and poultry.

- Agricultural Input Loans have a maximum loan amount of ETB 350 (USD 27) and a maximum loan term of 8 months. These loans are disbursed to Agricultural Extension Program beneficiaries for the purchase of inputs, such as soil fertilizer, pesticides and seeds. The government sponsored Agricultural Extension Program provides training to farmers, promotes agricultural research and disseminates technology to farmers. - Civil Servant Loans have a maximum loan amount of
ETB 8,000 (USD 628) and a maximum loan term of 24 months.

- Micro and Small Enterprise (MSE) Loans have a maximum loan amount of ETB 30,000 (USD 2,356) and a maximum loan term of $36-48$ months.

- Housing Loans information is not available.

DECSI offers two types of savings accounts: compulsory deposits of group and village center savings and voluntary deposits from individuals. DECSI's money transfer services also cover pension payment services for retired military and civil personnel.

A study commissioned in 2003 by DECSI and Norwegian People's Aid found that DECSI clients reported that their life situation had improved over five years as compared with non-clients. Compared to non-clients, DECSI clients found improvement in terms of income, consumption and assets. DECSI clients also seemed to have more food security and were less vulnerable to emergencies. Based on the constraints of the study, it was difficult to determine the economic and non-economic impact of DECSI at the community level. However, the study concluded that the existence of DECSI could be linked to increased agricultural productivity, improved market access and a reduction of interest rates charged by moneylenders.

DECSI receives funds and loans from international donors, government agencies and local sources. Donors of DECSI include the following: Norwegian People's Aid, International Fund for Population Development (IFPD), Glimmer of Hope, RUFIP Scheme and the International Agricultural Development Fund. DECSI has loans from the Development Bank of Ethiopia and the Commercial Bank of Ethiopia and receives matching funds from the Ethiopian government, including the Bureau of Trade and Industry and the Food Security Co-ordination Office.

\subsection{Problem Statement}

Performance of micro - finance institutions is relevant from the policy point of view because as finance growth literature suggests, if micro - finance institutions become betterfunctioning entities, it is expected to be reflected in strengthening capital buffer, safety and soundness of the financial systems (M. Joseph, 2007).

The Ethiopian microfinance sector is one of the fastest growing in the world today. As per the end of year 2005 the then 26 operational MFIs serviced 1,277,939 borrowing clients with an aggregated portfolio of 1,622 billion birr. In terms of outreach these figures represent a nearly $300 \%$ increase from end of year 2001 (Ethiopian micro finance institutions performance report, June 2007). The objective of almost all of the micro fiancé institutions in Ethiopia is poverty alleviation. To achieve these objective micro finance institutions should be financially viable and sustainable .Despite the increasing reliance on micro finance to reduce poverty in Ethiopia there has been surprisingly little work under taken to evaluate their performance. There is also a fear among interested parties in the industry that MFIs could not stay in the market to serve the poor without the immense support of government, donors and others. 


\section{International Journal of Science and Research (IJSR) \\ ISSN (Online): 2319-7064}

Index Copernicus Value (2013): 6.14 | Impact Factor (2015): 6.391

Thus, the purpose of this research is to evaluate the consolidated financial performance analysis of Dedebit credit and saving Institution. So far, few researches like Giday, 2011 and Hailay, 2013 have tried to assess only the operating and financial performance of the institution. Given this lack of empirical studies, it is hoped that this study fills a gap and provide useful support for better understanding of the overall performance analysis of Dedebit credit and saving institution.

The following research questions were answered by the study:

1) What seems the financial performance of Dedebit credit $\&$ saving institution over the years?

2) How is the operating profitability and efficiency of Dedebit credit \& saving institution over the years?

3) What are the indicators of the financial and operational performances of Dedebit credit \& saving institution over the years?

\subsection{Objectives of the Study}

\subsubsection{General Objective}

The general objective of the study is to evaluate the consolidated financial performance of Dedebit Credit and saving institution.

\subsubsection{Specific Objectives}

The specific objectives of the study were:

1) To analyze the financial performance of Dedebit credit \& saving institution over the years.

2) To evaluate the operating profitability and efficiency of Dedebit credit \& saving institution over the years.

3) To assess the indicators of the financial and operational performances of Dedebit credit \& saving institution over the years.

\section{Research Methodology}

\subsection{Research Design}

The objective of the research is to evaluate the consolidated financial performance analysis of DESCI. This study is a historical research based on case study approach. In any types of research study, the methodology /research design/ to be pursued is decided by the nature of the problem statement or more specifically by the research objectives. Here in this case study, the methodology is based on descriptive approach. Descriptive approaches is a technique used to organize and summarize a set of data in concise way; helps to identify the general features and trends in a set of data and extracting useful information; and also it is very important in conveying the final results of a study. Example: tables, graphs, numerical summary measures. (kibret, 2013).

\subsection{Data Source and Collection Methods}

The data used in this study was entirely a secondary data only. As the aim of this study is to evaluate the consolidated financial performance analysis, an audited financial statement of DECSI which has been reported to the National Bank of Ethiopia was used. Moreover, website (www.themixmarket.com), journals, annual and quarterly bulletins, news papers, data from books, publications, magazines, reports of different governmental and nongovernmental organizations like AEMFI (Association of Ethiopian Micro Finance Institutions), and National Bank of Ethiopia were used as the sources of secondary data.

\subsection{Methods of Data Analysis and Interpretation}

The data (i.e. audited financial statement reported to National Bank of Ethiopia) was coded and arranged in a way that is simple for analysis. Secondly, the arranged data have been analyzed using different statistical tools of data processing such as tables, charts, graphs and percentages. Besides, techniques of financial analysis, such as ratio analysis and trend analysis have been used to address the scientific evidence in the evaluation of consolidated financial performance of DECSI. The ratios were interpreted to determine the outcome of the analysis.

\section{Data Analysis}

\subsection{Introduction}

The collected data were analyzed using different financial and operating performance indicators, and ratio analyses were applied to evaluate the trend in performance of DECSI considered in this particular study. The findings presented below are produced and analyzed from the sum audited financial statements of DECSI reported to the National Bank of Ethiopia covering from the period of 2013 - 2015. In this section, the research paper states findings of the study on performance of financial sustainability and profitability; portfolio quality, and efficiency of DECSI over the study period.

\subsection{Financial Ratios and Trend Analysis Of Decsi}

In the following sub portions, the study tries to see the performance of DECSI from different financial ratios' viewpoints. This allows the reader to observe how the institution has been performing well or not also assesses the DECSI's performance by contrasting a year by year.

\subsubsection{Financial Profitability and Sustainability of DECSI} Sustainability of Microfinance Institutions (MFIs) is a continuous financial service provision to clients profitably as a going concern without depending on subsidies. Sustainability and Profitability ratios indicate the ability of microfinance institutions to continue operating and develop in the future periods of time. Most of good repute microfinance institutions are making every effort for sustainability, regardless of their for-profit or nonprofit condition; donors and investors similar to fund sustainable microfinance institutions. Numerous factors can influence profitability and sustainability of the institutions. However, beginner or fast growing institutions may have less profitability; they are building the foundation for a sustainable future. The ratios used in this section are the most broadly accepted profitability and sustainability indicators in the microfinance industry. These are:

1) Return on Assets (ROA),

2) Return on Equity (ROE), 


\section{International Journal of Science and Research (IJSR) \\ ISSN (Online): 2319-7064}

Index Copernicus Value (2013): 6.14 | Impact Factor (2015): 6.391

3) Operational Self-Sufficiency (OSS),

4) Dependency ratio

\subsubsection{Profitability Indicators of DECSI}

A) Return on Assets (ROA): - The return on Assets (ROA) reflects the organization's ability to deploy its assets profitably. Hence, in this study the ROA reflects how well DECSI has been managing its assets to improve and maximize its profitability over the study period i.e. 2013 - 2015. The ROA ratio contains not only the return on the portfolio, but also any other income generated from investments and other operating activities of the institution. The ROA is computed by the following formula:

$$
\text { ROA }=\frac{\text { Net operating income after tax }}{\text { Average total assets }}
$$

Table 4.1: Return on Assets ratio

\begin{tabular}{|c|c|c|c|}
\hline & $\mathbf{2 0 1 3}$ & $\mathbf{2 0 1 4}$ & $\mathbf{2 0 1 5}$ \\
\hline $\begin{array}{c}\text { Net operating } \\
\text { profit after tax }\end{array}$ & $53,820,100$ & $109,089,000$ & $120,134,300$ \\
\hline $\begin{array}{c}\text { Average total } \\
\text { assets }\end{array}$ & $3,277,546,800$ & $3,881,417,700$ & $4,593,154,100$ \\
\hline ROA (\%) & $\mathbf{1 . 6 4 \%}$ & $\mathbf{2 . 8 1 \%}$ & $\mathbf{2 . 6 2}$ \\
\hline
\end{tabular}

Source: Researchers' own computation from financial statement

As the above table 4.1 indicates, the performance of DECSI in managing its assets to generate a net profit has been positive all over the study periods. Although, the ROA in 2014 G.C was greater than the previous year's, DECSI's ROA was slightly decreased in 2015 G.C.

B) Return on Equity (ROE): - The return on equity (ROE) reflects the organization's ability to deploy its investors' investments profitably. Hence, in this study the ROE reflects how well DECSI reward its investors' investment, make its equity base by means of retained earnings, and increase additional investment over the study period. For non-profit MFI, return on equity reflects its ability to produce equity by retained earnings; and raised equity allows the MFI to leverage (influence) additional financing to raise its portfolio. The ROE is computed by the following formula: ROE $=\frac{\text { Net operating prof it after tax }}{\text { Average total Equity }}$

Table 4.2: Return on Equity

\begin{tabular}{|c|c|c|c|}
\hline & $\mathbf{2 0 1 3}$ & $\mathbf{2 0 1 4}$ & $\mathbf{2 0 1 5}$ \\
\hline Net operating profit after tax & $53,820,100$ & $109,089,000$ & $120,134,300$ \\
\hline Average total Equity & $763,230,450$ & $846,767,250$ & $967,129,950$ \\
\hline ROE (\%) & $\mathbf{7 . 0 5 \%}$ & $\mathbf{1 2 . 8 8 \%}$ & $\mathbf{1 2 . 4 2}$ \\
\hline
\end{tabular}

Source: Researchers' own computation from financial statement

The above table 4.2 depicted that DECSI had a ROE of $12.88 \%$ in 2014 which was the highest figure from the rest of the study periods. In 2015 DECSI's ROE was slightly reduced compared to that of the preceding year.

\subsubsection{Financial Sustainability Indicators of DECSI}

Financial sustainability is the degree to which an institution collects sufficient revenues from sale of its services to cover the full costs of its activities, evaluated on an opportunity- cost basis. Full financial sustainability is allowing continuing operating at a stable or growing scale without ongoing support from external supporters such as governments, donor agencies, or charitable organizations. In this section, the study tries to see two main ratios that are widely used to measure the continuity of a financial institution. As indicated above sustainability is one and the fore most objective of any institution. In microfinance industry now a day the main intention of any concerned body is to address this critical issue, because the first goal of most MFIs is to change the lives of the poor in a continuing manner, so, to achieve this goal institutions should have to be sustainable.

These institutions, to continue serving the poor societies, their profitability and sustainability should be measured, because they need to be operationally and financially sustainable. Among the available measures, operational selfsufficiency and financial self-sufficiency are the predominant profitability and sustainability measurement variables. This has been needed because mostly they rely on the funds which are obtained from donors. The problem is not about relaying on them, but it is about what if the donation is terminated at some point in time.

Sustainability in this study was measured by operational self-sufficiency, dependency ratio, and Non-performing loan (NPLs) to loan outstanding ratio of the microfinance institution.

A) Operational Self-Sufficiency (OSS): is the most basic measurement of sustainability, indicating whether revenues from operations are sufficient to cover all operating expenses. It reflects the DECSI's ability to continue its operations if it receives no further subsidies. As with the preceding measures of returns, OSS focuses on revenues and expenses from the institution's core business, excluding non operating revenues and donations. The breakeven point of OSS is 100 percent. The value of 1 (or 100\%) and above for OSS variables shows that the microfinance institutions are operationally self-sufficient but the value below 1 (or $100 \%$ ) shows they have not yet achieved financial breakeven and also not sustainable. OSS is computed by the following formula:

Financial Revenue

$\overline{\text { Financial Expense + Impairement losses on loans + Operating Expense }}$

Table 4.3: Operational self-sufficiency

\begin{tabular}{|c|c|c|c|}
\hline & $\mathbf{2 0 1 3}$ & $\mathbf{2 0 1 4}$ & $\mathbf{2 0 1 5}$ \\
\hline Financial Revenue & $298,909,600$ & $372,459,000$ & $478,719,800$ \\
\hline FE + ILOL + OE & $245,089,500$ & $263,370,000$ & $358,585,500$ \\
\hline OSS & $\mathbf{1 . 2 2}$ & $\mathbf{1 . 4 1}$ & $\mathbf{1 . 3 4}$ \\
\hline
\end{tabular}

Source: Researchers' own computation from financial statement

According to the above table 4.3, DECSI's operational selfsufficiency was above the threshold of 1. i.e. all over the study years the institutions' OSS were more than 1 which implies the institution's operating revenue is sufficient enough to cover all of its operating expenses. 


\section{International Journal of Science and Research (IJSR) \\ ISSN (Online): 2319-7064}

Index Copernicus Value (2013): 6.14 | Impact Factor (2015): 6.391

B) Dependency Ratio (DR): - Subsidy is a crucial factor in analyzing sustainability of microfinance in general and MFIs in particular. Majority of microfinance programs in the world are subsidized in different ways; sustainability of the programs poses a question in the mind of academics and researchers. The DR is computed by the following formula:

$$
\text { DR }=\frac{\text { Donated Equity }}{\text { Total Capital }}
$$

Table 4.4: Dependency ratio

\begin{tabular}{|c|c|c|c|}
\hline & $\mathbf{2 0 1 3}$ & $\mathbf{2 0 1 4}$ & $\mathbf{2 0 1 5}$ \\
\hline Donated Equity & $122,108,500$ & $122,744,700$ & $131,278,100$ \\
\hline Total Capital & $790,736,900$ & $902,797,600$ & $1,031,462,300$ \\
\hline DR & $\mathbf{1 5 . 4 4 \%}$ & $\mathbf{1 3 . 6 0 \%}$ & $\mathbf{1 2 . 7 3 \%}$ \\
\hline
\end{tabular}

Source: Researchers' own computation from financial statement

A study by Peter (2007) shows a negative relationship between the financial sustainability of an institution and the level of subsidies received each quarter. As the level of subsidy income rises, the respective institution's financial sustainability falls. Many have argued that subsidies help microfinance institutions reach the needed operational size. However, as discussed in many previous studies, these institutions may actually be doing less good as they receive more assistance. Besides, institutions with more subsidy income have higher level of loans outstanding that is greater scale. This result may reflect the crowding out effect described above - an increasing amount of grants and other subsidies are being directed to microfinance institutions that have already achieved a level of operations needed for their own continued success. Likewise, Kereta (2007) found that there is a negative relationship between dependency ratio and financial sustainability, and he further explains as reduction in dependency ratio (as dependency ratio measured by the ratio of donated equity to total capital) decline over the years in the MFI industry is an indication that MFIs can be self-sustainable, profitable, and meet their social missions and letting the industry to be financial selfsufficient.

Hence, according to the DR results presented in table 4.4, DECSI's dependency ratio has been decreasing from year to year $(15.44 \%$ in 2013 to $13.60 \%$ in 2014 and again reduced to $12.73 \%$ in 2015 ) all over the study periods which is a good indicator that the institution has been able to increase its rely on own equity and operational revenues.

\subsubsection{Portfolio Quality (Loan Repayment) of DECSI}

The loan portfolio is the highest vital asset of microfinance institution. Loan portfolio quality is reviews how the microfinance institution measures, monitors, and manages its loan portfolio, together with delinquency and write-offs. Portfolio quality indicates the risk of loan delinquency and influences future earnings and the microfinance institution's ability to extend outreach and serve current clients.

This is the most making known of the five performance areas. A money lender's ability to collect loans is essential for its success: if delinquency is not maintained to very low levels, it can rapidly spin out of control. Moreover, loan collection has verified to be a powerful proxy for general management competence.
Table 4.5: Portfolio Quality performance of DECSI

\begin{tabular}{|c|l|l|l|}
\hline \multirow{2}{*}{ Indicators } & \multicolumn{2}{|c|}{ years } & \\
\cline { 2 - 4 } & 2013 & 2014 & 2015 \\
\hline PAR $>$ 30 days (Non-performing loans) & $2.06 \%$ & $1.78 \%$ & $1.75 \%$ \\
\hline Write-off ratio & $0.61 \%$ & $0.42 \%$ & $0.28 \%$ \\
\hline
\end{tabular}

Source: Researchers' own computation from financial statement

\section{A) Portfolio at risk (PAR) $>30$ days (Non-performing} loan) of DECSI

Portfolio quality is measured as portfolio at risk over 30 days. PAR ratio measures existing degree of risk in the total microfinance portfolio at a point in time. It provides a picture of the loan portfolio which is at risk of not being paid. It measures how much you could lose if all borrowers with late payments default. Changes to PAR ratio may show changes in risk, but should be examine in combination with the write-off ratio, as the level of reported non-perform loans can be reduced through write-offs. A decreasing PAR signals a healthy loan portfolio. The age (degree of lateness) of the missed payment is stated in days. The principal balance of loans with missed payment is calculated as to number of days late.

Portfolio at risk $($ PAR $)>30$ days $=($ Outstanding loan balance, portfolio overdue > 30 Days+ renegotiated portfolio) / Gross Loan Portfolio

The higher PAR shows low loan repayment rates, as sign of inefficient microfinance institution. The greater the PAR, the higher inefficient the microfinance will be and, so, the less financially sustainable of the microfinance institution. CGAP, 2009 stated that as a rough rule of thumb when dealing with uncollateralized loans, PAR or LAR (30 days or one payment period) more than $10 \%$, or ALR more than $5 \%$ must be minimized quickly or they will spin out of control.

The above result of PAR> 30 Days of DECSI showed that $2.06 \%$ in $2013,1.78 \%$ in 2014 , and $1.75 \%$ in 2015 . This decreasing PAR indicates a healthy loan portfolio.

B) Write-off ratio of DECSI: - It is a measure the percentage of the microfinance institution's loans that has been eliminated from the balance of the gross loan portfolio because they are improbable to be pay back. Changes write-off ratio should be interpret in combination with the PAR> 30 Days ratio, as MFIs may keep risk on their balance sheets.

Write-off ratio $=\underline{\text { Value of loans written-off }}$

Average Gross Loan Portfolio

A decreasing write-off ratio shows a healthy loan portfolio. Write-off ratio of DECSI was $0.61 \%$ in year 2015 and this was gradually reduced to $0.28 \%$ as of 2015 and indicated better write-off ratio than the write-off ratio of the previous years.

\subsubsection{Efficiency Ratio of DECSI}

Efficiency ratios provide information about the rate at which the MFI generate income to cover their cost. These indicators show how well DECSI utilizes its assets. Efficiency refers to cost per unit of output generated for a 


\section{International Journal of Science and Research (IJSR) \\ ISSN (Online): 2319-7064}

Index Copernicus Value (2013): 6.14 | Impact Factor (2015): 6.391

given input (total assets). This study used operating expense ratio as efficiency indicator.

\subsubsection{Operating expense ratio: -}

According to CGAP (2009), operating expense ratio is the most generally used measure of microfinance efficiency. It indicates administrative and personnel expense of the institution yield on the gross loan portfolio. Operating expense ratio is the percentage of operating expense to average gross loan portfolio. It measures how the microfinance institution's management has been efficient in minimizing operating expenses at a given level of operation. The operating expense ratio is computed as follows:

$$
\mathrm{OER}=\frac{\text { Operating Expense }}{\text { Average Gross loan portfolio }}
$$

Table 4.6: Operating Efficiency ratio

\begin{tabular}{|c|c|c|c|}
\hline & $\mathbf{2 0 1 3}$ & $\mathbf{2 0 1 4}$ & $\mathbf{2 0 1 5}$ \\
\hline $\begin{array}{c}\text { Operating } \\
\text { Expense }\end{array}$ & $194,737,100$ & $263,370,000$ & $290,054,100$ \\
\hline $\begin{array}{c}\text { Average gross } \\
\text { loan portfolio }\end{array}$ & $1,454,996,400$ & $1,919,509,650$ & $2,207,956,750$ \\
\hline OER & $13.38 \%$ & $13.72 \%$ & $13.14 \%$ \\
\hline
\end{tabular}

Source: Researchers' own computation from financial statement

The lower the operating expense ratio will show efficiency in microfinance institutions' cost minimization strategy. The lesser the ratio, all things being equal, the greater efficient the institution is. With this regard, DECSI attains lower ratio (i.e., 13.14\%) in the year 2015. From this, one can conclude that DECSI incurred almost 13 cents for administration and personnel (operating) expense in turn to provide a $\$ 1$ average gross loan portfolio to its customers in the year 2015.

\section{Conclusion and Recommendations}

This chapter presents the conclusion of the study, possible recommendation, as well as future research directions.

\subsection{Conclusion}

The collected data were analyzed using different financial and operating performance indicators, and ratio analyses were applied to evaluate the trend in performance of DECSI considered in this particular study. The study concentrated on performance of financial sustainability and profitability, portfolio quality, and efficiency of DECSI over the study period.

To evaluate the Financial Profitability and Sustainability of DECSI, Return on Assets (ROA), Return on Equity (ROE), Operational Self-Sufficiency (OSS), and Dependency ratios were used. Portfolio at risk (PAR) $>30$ days, and Write-off ratios were used to assess the portfolio quality of the institution. Moreover, operating efficiency ratio was used to evaluate the operating efficiency of the institution. Hence, based on the findings of the data analyses, the researchers have made the following conclusions:

The performance of DECSI in managing its assets to generate a net profit has been positive all over the study periods. Although, the ROA in 2014 G.C was greater than the previous year's, DECSI's ROA was slightly decreased in 2015 G.C.

DECSI had a ROE of $12.88 \%$ in 2014 which was the highest figure from the rest of the study periods. In 2015 DECSI's ROE was slightly reduced compared to that of the preceding year.

DECSI's operational self-sufficiency was above the threshold of 1, i.e. all over the study years the institutions' OSS were more than 1 which implies the institution's operating revenue is sufficient enough to cover all of its operating expenses.

According to the DR results, DECSI's dependency ratio has been decreasing from year to year $(15.44 \%$ in 2013 to $13.60 \%$ in 2014 and again reduced to $12.73 \%$ in 2015) all over the study periods which is a good indicator that the institution has been able to increase its rely on own equity and operational revenues.

With regard to the operating efficiency, DECSI attains lower ratio (i.e., $13.14 \%$ ) in the year 2015. From this, one can conclude that DECSI incurred almost 13 cents for administration and personnel (operating) expense in turn to provide a $\$ 1$ average gross loan portfolio to its customers in the year 2015 .

\subsection{Recommendations}

Based on the findings of the study the following recommendations are made by the researcher:

- Since return on assets and return on equity of DECSI greater than zero, it should perform on it to move towards highest return and to get performance consistency or stability. In assessing the fact that these parameters are the means to survive and grow to provide sustained service to the poor without any subsidize and support of fund from external parties.

- As it has been discussed in the analyses part, although the sign of decreasing PAR and write - off ratios indicates a healthy loan portfolio, the annual PAR and write - off ratio figures cannot be considered as negligible. Therefore, the institution should strive to minimise the PAR and write - off ratio amounts by a higher margins.

- DECSI should minimise its operating expense ratios as there are possible rooms to do so.

\section{References}

[1] Alemayehu Yirsaw (2008). The performance of Micro Finance Institutions in Ethiopia: A case of six microfinance institutions

[2] www.kiva.org/about/microfinance

[3] Jacob Yaron and Ronny Manos (2007). Determining the Self Sufficiency of Microfinance Institutions

[4] Bamlaku Alamirew Alemu (2006). Microfinancing and Poverty Reduction in Ethiopia

[5] http://www.bds-ethiopia.net/finance/dedebit.html

[6] Hailay Alem (2013). Assessment of financial and operating performance of Micro finance institutions. 


\section{International Journal of Science and Research (IJSR) \\ ISSN (Online): 2319-7064}

Index Copernicus Value (2013): 6.14 | Impact Factor (2015): 6.391

[7] Dejene A. (2003). Gender and Micro Finance in Africa; Micro Finance Development Review, Vol. 2 No. 4, AEMFIs, Quarterly Bulletin, Addis Ababa

[8] Befikadu, B.(2007) .Outreach and Financial Performance Analysis of Microfinance Institutions in Ethiopia, National Bank of Ethiopia Economic Research and Monetary policy Directorate. Africa Economic Conference United Nations Conference Center (UNCC), Addis Ababa, Ethiopia.

[9] Fikire k. Reta (2011), Determinants of loan repayment performance, Wageningen University, Netherlands, pp 40.

[10] Kereta, B. (2007), Outreach and Financial Performance Analysis of Microfinance Institutions in Ethiopia African Economic Conference United Nations Conference Center (UNCC), Addis Ababa, Ethiopia 1517 November

[11] Navajas, S., M. Schreiner, R. L. Meyer, C. GonzalezVega and J. Rodriguez-Meza (2000), "Micro credit and the Poorest of the Poor: Theory and Evidence from Bolivia", World Development, Vol. 28, No. 2, pp 333346, Elsevier Science Ltd.

[12] Nawaz, A. (2009), EEfficiency and productivity of microfinance: incorporating the role of subsidies" University of Goettingen, Oec I-157, 37073 Goettingen, Germany

[13] Otero, M. and Rhyne, E. (1994). The New World of Micro - enterprise Finance: Building Healthy Financial Institutions for the Poor. Intermediate Technology Publications, London, U.K.

[14] Dowla, A. and Alamgir, D. (2003), 'From Microcredit to Microfinance: Evaluation of Savings Products by MFIs in Bangladesh', Journal of International Development, Vol. 15, No. 8, pp. 969-988.

[15] Economist (2005), 'The Hidden Wealth of the Poor', Economist, November 5, Vol. 377 Iss. 8451, p. 3.

[16] Francisco, M., Mascaró, Y., Mendoza, J.C. and Yaron, J. (2007), 'Measuring Performance and the Achievement of Social Objectives of Development Financial Institutions (DFIs)', World Bank Working Paper, forthcoming 